\title{
ISLAMIC VALUES IN INCLUSION LEARNING MANAGEMENT IN SCHOOL OF LIFE LEBAH PUTIH SALATIGA
}

\author{
Nuridin \\ Primary School Teacher Education Program, Sultan Agung Islamic University \\ Email: nuridin@unissula.ac.id \\ Jupriyanto \\ Primary School Teacher Education Program, Sultan Agung Islamic University \\ Email jupriyanto@unissula.ac.id \\ Elvrida Rosalia Indraswari \\ Primary School Teacher Education Program, Sultan Agung Islamic University \\ E-mail: $\underline{\text { adyrosa70@ gmail.com }}$
}

\begin{abstract}
Abstrak
Tujuan dari penelitian ini untuk menggambarkan: (1) perencanaan (2) pengorganisasian; (3) implementasi: dan (4) sistem penilaian pembelajaran inklusif di Salatiga White Bee School of Life. Penelitian ini menggunakan pendekatan kualitatif. Subjek penelitian adalah Kepala Sekolah dan fasilitator. Teknik pengumpulan data menggunakan wawancara semi-terstruktur, observasi partisipatif, dan studi dokumentasi YANG kemudian dianalisis dengan reduksi data, tampilan data, dan penarikan kesimpulan data. Berdasarkan hasil penelitian dapat disimpulkan bahwa: (1) perencanaan meliputi; kurikulum yang digunakan adalah KTSP dengan beberapa modifikasi, semua fasilitator dan konsultan sekolah terlibat dalam menetapkan rencana pembelajaran; (2) pengorganisasian meliputi; pengorganisasian tata letak pembelajaran, sumber daya pembelajaran, dan metode serta media dalam pembelajaran, (3) pelaksanaan meliputi; pengembangan keterampilan hidup dan menemukan identitas, memprioritaskan belajar menyenangkan, dan fasilitator yang membantu ABK, dan (4) sistem penilaian meliputi; penilai otentik, dan kartu laporan untuk $A B K$.
\end{abstract}

Kata Kunci: Manajemen pembelajaran, inklusi, pembelajaran menyenangkan, kecakapan hidup.

Abstract
The aim of this study is to describe: (1) planning (2) organizing; (3) implementation: and (4) inclusive learning assessment system at the Salatiga White Bee School of Life. This research uses a qualitative approach. The research subjects were the Principal and facilitator. Data collection techniques used semi-structured interviews, participatory observation, and documentation studies which were then analyzed by data reduction, data display, and drawing data conclusions. Based on the results of the study it can be concluded that: (1) planning includes; the curriculum used is KTSP with some modifications, facilitators, and school consultants are involved in setting learning plans; (2) organization includes; organizing learning layouts, learning resources, and methods and media in learning, (3) implementation includes; development of life skills and finding identities, prioritizing enjoyable learning, and facilitators who help $A B K$, and (4) the assessment system includes; authentic appraisers, and report cards for $A B K$. Keywords: Learning management, inclusion, fun learning, life skills. 


\section{A. Preliminary}

The child is a mandate as well as a gift given by the Most Great, Allah Almighty to a servant. Proper upbringing of a child will make pious child and useful for religion, nation and country. The Indonesian people need a generation that is pious and able to deliver Indonesia to the future and glory.

To deliver Indonesia towards progress and glory, an education is needed. Both according to religious and state views, education is clearly an important thing. Implicit in the importance of an education, Allah says in QS Al Mujadalah verse 11, which means "Allah will exalt the believers among you and those who are given Science a few degrees" (Surat al-Mujadalah: 11). This verse confirms that the person who possesses the Science will be appointed by the Most Great, Allah SWT. People who have knowledge will be respected by many people and gain trust in managing whatever happens in this life. It needs to be an underscore if a person is faithful but, not knowledgeable, he will be weak. Faith without knowledge will not be strong and knowledgeable without faith is error.

In addition to religious views, the state also holds the important role of education in the Act No. 20 of 2003, Article 3 states that National Education functions to develop the ability and form dignified national character and civilization in order to educate the life of the nation, aiming to develop the potential of students to become human beings who are faithful and devoted to God Almighty, noble, healthy, knowledgeable, capable, creative, independent, and a democratic and responsible country. As mentioned above, religion and the state has emphasized education is important and a benchmark for the success of a generation. Education does play a role in human life, to understand itself and its needs.

Departing from the important role of education, all children should have the opportunity to go to school with good and quality education in order to meet the glorious future of the Indonesian nation, including children with special needs. Good and quality education is education that accepts students with the same conditions and intelligence, including children with special needs. Then good education includes planning, organizing, implementing and a good assessment 
system. Also good planning in this case the lesson plan is consulted in advance, whether it has fulfilled the content standardization with indicators of achievement that can be achieved through learning activities. Lesson plan was good and the quality is a continuous lesson plan objectives include $\mathrm{SK}, \mathrm{KD}$, indicators and outcomes of learning.Second, it contains a balanced bloom taxonomy of knowledge, understanding, application, analysis, synthesis and evaluation for each KD. Third, there is a match between the indicators of achievement and teaching activities and their design following the brain pattern of students while the learning activities are in accordance with learning styles and intelligence.

In terms of the implementation of learning, good education focuses on the best learning process and uses learning strategies that concern students' multiple intelligences and as well as in their assessment using authentic assessment. Basically learning is one process to develop the skills and abilities of students. The teacher becomes the main actor in a class defense in class. The teacher is not only as a transfer of knowledge but also as an active facilitator to develop the active potential that exists in his students. A teacher is an actor who plans various learning activities and implements to his students by considering the learning strategies applied and determining alternatives in overcoming obstacles and challenges in the learning process.

All children in a variety of conditions, including Children with Special Needs, are like being in a classroom to study without regard to deficiencies or strengths and accommodate the diversity of students. This is confirmed in Act No. 20 of 2003, Chapter V, Article 5 paragraph 1 which can be concluded that Children with Special Needs have rights that guarantee the continuity of their education, even Children with Special Needs have the right to have the opportunity to improve education throughout life. Rizzo (2009:3), argues that Children with Special Needs are:

'Children are significantly different in several important dimensions of their human function. Those who are physically, psychologically, cognitively or socially inhibited in achieving their goals / needs and potential maximally, include those 
who are deaf, blind, have speech impairments, disabilities, mental retardation, emotional disturbances. Also children who are gifted with high intelligence, can be categorized as special / extraordinary children, because they require trained staff from professional staff.

However, what happens today is that there is often debate in seeing whether the education provided to children with special needs is separation or inclusion. Children with special needs are often considered and feel as a "guest" in the regular class who are just given permission to be in class without full rights and admit they are part of the class (Mangunsong, 2009:17). In fact, everyone is happy to be recognized. Receiving recognition makes us feel proud, confident, and happy (DePorter, 2013: 61).

Inclusion is the answer to exclusion commonly known as SLB (Special Schools). Inclusion is a new breakthrough and innovation from integrated education. " Inclusion fish instructors are intended as an educational service system that involves children with special needs to learn with their peers in regular schools closest to their homes" (Triani, 2013: 4). The presence of Inclusion is an effort to underminethe limitations that have been in the minds of people who claim that Children with Special Needs must study in special places as well.

"In the environment of inclusion, a teacher is ready to change and adjust the system, environment and activities related to everyone and consider the needs of all people, not children with disabilities who have to adjust to fit the existing settings" (Mangunsong, 2009: 17) This inclusive education has good benefits for the community and children with special needs themselves. In terms of society, the community will begin to accept the presence of children with special needs. Whereas in terms of Children with Special Needs, the presence of Inclusive Education enables them to be able to learn with other normal children and be treated as normal children, and in fact Children with Special Needs who study Inclusive education will have better social competence.

Then based on interviews with community learning mentors and preresearch activities, researchers obtained information including: 1) School of 
Life Lebah Putih Salatiga is a public school that is packaged non- formally based on inclusive education and emphasizes equality, social solidarity that education is for all. 2) School of Life Lebah Putih Salatiga, all children have the same learning experience.The learning environment created is a conducive and enjoyable learning environment in accordance with the needs and learning styles of each child. In addition, all children are also helped to develop their interests and talents and their positive character based on their respective intelligence. 3) The implementation of School of Life Lebah Putih Salatiga uses the KTSP curriculum which is formulated in the style of School of Life Lebah Putih Salatiga and adapted to the concept of Inclusion learning.

This research departs from researchers' interest in inclusive learning that provides learning opportunities for children with special needs to be the same as other friends. Based on the description, the researcher chose the title "Management of Inclusion Learning in School of Life Lebah Putih Salatiga".

This study uses a qualitative approach. The location of this research was carried out at Elementary School of Life Lebah Putih located at Sidomulyo Street, RT 6/15 Mangunsari, Sidomukti, Salatiga City, Central Java 50721. In conducting data collection, qualitative research acted as a human instructor, which functions in determining a research focus, selecting informants as data sources, conducting data collection activities, assessing the quality of the data, and then analyzing and drawing conclusions on their findings.

The focus of the research on this research is how to plan, organize, implement, and research systems in School of Life Lebah Putih Salatiga. Data collection techniques that researchers use are moderate and candid or subtle observation, semi- structured interviews, and documentation. The data analysis technique used in this study is the data analysis technique with the Miles and Huberman Model which includes data reduction, data display, and data conclusion. Then after analyzing the data, the researcher tested the validity of the data using triangulation of data. 


\section{B. Discussion}

\section{Planning for Learning Inclusion in School of Life Lebah Putih Salatiga}

Based on the results of the study, the planning plan of School of Life Lebah PutihSalatiga inclusion included : (a) the curriculum used was KTSP which was formulated in the style of Lebah Putih; (b) all zone facilitators, and school consultants are involved in establishing learning plans.

First, the curriculum used is KTSP which is formulated in the style of Lebah Putih. Lesson plan in School of Life Lebah Putih for grades 1-3 is not based on subjects but on zones. In the IC(Intellectual Curiosity) zone, the subject taught into a learning topic is Indonesian and English. In the CI (Creative Imagination and Invention) zone, the folders are Art, Javanese Language and Sports. Then in maple AD (Art of Discovery) zones which are taught to become learning topics namely Mathematics and Science. Finally, the map of the NA (Noble Attitude) zone that covers it is IPS, Civics and Islamic Religion. However, basically in each learning topic that is taught always contains the four zones. On each topic the students are always excavated their curiosity (IC) and then imagine about what they can do (CI) which eventually the students can find a concept from what they have done (AD) and can be grateful for life and practice the knowledge that has been get to the surrounding (NA). Each zone in grades 1st-3rd will be covered by one facilitator, so each zone facilitator plays a role in making a zone lesson plan. The focus and attention in planning inclusive learning in the White Bee is to plan and create enjoyable learning and develop students' talents and interests.

Secondly, related to the making of lesson plans, the results of the study also said that School of Life Lebah Putih facilitators were required to deposit a maximum weekly lesson plan on Saturdays. The lesson plan was uploaded to google drive which can be accessed by Ms. Lilis, Mrs. Septipeni, and zone facilitators. Mrs. Lilis is a School of Life Lebah Putih consultant who will control the preparation of the lesson plan and provide advice or input on the lesson plan that the facilitator has made . Besides Mrs. Lilis, Mrs. Septipeni as the founder of Jarimatika and education observers will also control the lesson 
plan.Controlling and providing lesson plan includes whether the inclusive learning plan that has been made is in accordance with School of Life Lebah Putih concept that prioritizes fun learning.

In the lesson planning, School of Life Lebah Putih does not have a specific training for teachers regarding the understanding and procedures for learning Inclusion. It's just that occasionally the chairman of the foundation came to share with the facilitator about the handling of Children with Special Needs. School of Life Lebah Putih in its planning also has regular discussion activities of the facilitators with the Head of the Seko, which is called a briefing which is held in the morning and afternoon. The purpose of this briefing is to create innovations in implementing inclusive learning and solving existing learning problems. There is no difference between lesson plan for ordinary children and children with special needs. Differences will later be placed on worksheets and assessments.

\section{Organizing Inclusion Learning in School of Life Lebah Putih Salatiga}

Based on the results of the Organizing research include: (a) organizing learning layout, (b) learning resources, and (c) methods and media in learning.

First, the layout of the classroom in School of Life Lebah Putih is as comfortable as possible so that students can actively express and move. Students' study rooms are not limited to their classrooms but can exchange classes with other classes and can learn in a more open environment such as a playground and School of Life Lebah Putih field. This is in line with Chatib (2013:33) who says that classroom must be fun and let each talk in an opinion. Chatib (2013:2) also said that the layout of the class or classes display can improve student learning spirit and produce as well as showing his work.

School of Life Lebah Puth uses a variety of learning resources in organizing inclusive learning. The biggest learning source for School of Life Lebah Putih is the environment because basically the environment has provided a lot of knowledge to be explored. While the sources come from printed books. School of Life Lebah Putih does not use certain books to support the implementation of inclusive learning. Part of the facilitator is free to use a 
variety of different sources, in other words, not only one book. This is also in line with Chatib (2011: 203) who said that learning resources are the source used in the learning process. Learning resources can be in the form of environment, printed books, characters and others.

The learning strategy is a derivative of the learning approach that is still conceptual, contains the meaning of planning, and in its implementation a variety of learning methods are needed. The facilitators in School of Life Lebah Putih are also given freedom in enhancing creativity through the use of learning strategies and methods as well as the media. The strategies and methods used are certainly fun. Of course this is adjusted to the learning topic that will take place. Then both the strategies, methods and learning media are the same for both ordinary children and children with special needs. This is in line with Chatib's opinion that being a teacher must also teach in a fun way because basically the teacher plays with the child's brain, the teacher must satisfy the child's brain with many fun methods and with pleasant media as if the child is not feel that you are studying.

\section{The Implementation of Inclusion Learning}

The implementation includes a) the students are guided to develop life skill and to find out the identity. b) The learning in lebah putih prioritizes the interesting learning. c) There is a facilitator who has a role to assistExceptional Children(ABK).

First, in LebahPutihthe students are guided to develop life skill and to find out the identity

Secondly, the learning in lebah putih prioritizes the interesting learning by the activity of learning includes 1) opening, 2) main activity (start from the finish line, hook, explore dan get connected), 3) closing activity. Before entering the class the students are invited to pray dhuha together, garbage detective, morning activity. Then continued with the opening activities are greeting, Du'a, student attendance, and asking how the students are. The implementation of learning activities starts at the main activities with activities start from the finish line that contain apperception and condition of the alpha zone of students and 
identification and classification of something from the event told by the facilitator. Then the hook contains question and answer and explanation of the game procedures to be carried out in explore activity. In explore activity, the students will explore their ability with various activities. While in get connected the students will find a new concept. Last is the closing activity the facilitator and the students will conclude what they have been learnt together, so the learning closed with du'a, greeting and question and answer. In the closing activity includes NA zone where children are invited to understand that everything comes from Allah and from a knowledge we can be grateful for all His creation.

A review of Surat Al Alaq on the NA (Noble Attitude) zone concept is as follows:

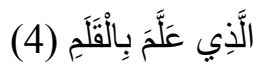

"Who taught knowledge by the pen"

Knowledge is conveyed through teaching and word (in Arabic Language called Kalam). Allah conveys knowledge to humans then that knowledge was to get closer to Him. If synchronized with QS. Al Alaq then it is in accordance with the 4th verse which means "Who taught knowledge by the pen". The intercession of the kalam here is both teaching and words.

عَلَّمَ الْإِنْسَانَ مَا لَمْ يَعْلَمْ (5)

"taught man what he did not know"

Since with knowledge man can know everything as has been exemplified in the description of research about looking for the concept of circumference object. The source of knowledge is aimed to Allah SWT TheOmniscient (in Arabic Language called 'Aalimuun). If synchronized with QS. Al Alaq then it is in accordance with the 5th verse which means "taught man what he did not know". "He" in this verse is the real teacher. The real teacher is Allah SWT.

Then in terms of $\mathrm{Al}$ Ghazali's philosophy of education, as follows:

"Indeed the result of knowledge to stay ourselves closer to Allah, The God of Universe. Connect yourself with the glory of angels, and have high abilities like angels". 
In the word "result" it showed the process, while "stay ourselves closer to Allah" it showed the purpose, then the word "knowledge" it showed the tool. If synchronized with Al Ghazali's philosophy of education then it is in accordance with "Indeed the result of knowledge to stay ourselves closer to Allah, The God of Universe. Connect yourself with the glory of angels, and have high abilities like angels".

The knowledge is a tool to stay ourselves closer to Allah SWT. Because in the knowledge obtained, humans can be grateful for the blessings given by the Creator to him.

Based on review QS Al Alaq verses 4 and 5 as well as Al Ghozali's philosophy on the concept of the NA zone (Nobble Attitude) can be concluded that Allah SWT is a real human teacher and He teaches Knowledge to humans through a word (teaching). Where the knowledge is a tool to get closer to Him and be grateful for all His creation.

Furthermore, the implementation of learning above 11.00 will be accompanied by one facilitator whose role to help Exceptional Children. In the implementation The School of lifeLebahPutih has several special programs for Exceptional Children, including class atmosphere, psychology, periodic psychological counseling, and consultation with a psychologist. The atmosphere class is a special class for Exceptional Childrenwhich is held every two weeks.

\section{The Assessment system for Inclusion learning in the School of Life Lebah Putih Salatiga}

Based on the research, the Assessment system for Inclusion learning in the School of LifeLebahPutihincludes, a) the assessment used is authentic assessor, b) there are two report cards for Exceptional Children(ABK). The assessment system in Schoolof lifeLebahPutihapplies authentic assessment which includes the balance of three domains of assessment, namely the affective, psychomotor, and cognitive domains. Affective assessment is based on observations of daily facilitators. Psychomotor assessment through project, discussion and presentation. Cognitive assessment through written and oral test. Written tests such as worksheets while oral tests in the form of questions and answers. 
Worksheets, Midterm Exam (UTS), and Final Exam(UAS) given to ordinary children and Exceptional Childrenare different. For Exceptional Childrenthe grade of the questions will be lowered slightly from the questions for ordinary children.

The assessment is carried out by each zone facilitator. Then for the results of the assessment will be given to the homeroom to be processed in the report card. The report card from grade 1-3 Schoolof LifeLebahPutih consists of the value of the subjects of each zone, morning activity / star class activities, and student personality development. Besides producing the score, the report cardschool of life Lebah Putih also showed the description. If the ordinary children only get a general report cardschool of life Lebah Putih, then Exceptional Children will get two report cards. Report cards received by children with special needs are general report cards and special report cards.

\section{Conclusion}

Based on the description of the results of the research and discussion it can be concluded that:

1. The Implementation of Inclusive Learning School of life Lebah Putih Salatiga includes a) the curriculum used is KTSP which is formulated in the style of LebahPutih, b) all the zone fasilitator, and school consultants are involved in setting learning plans.

2. Organizing includes: (a) organizing learning layouts, (b) learning resources, and (c) methods and media in learning.

3. The implementation includes: (a) the child is guided to develop life skills and to find out their identity; (b) learning at LebahPutih prioritizes enjoyable learning; (c) there are facilitating facilitators who have the role to help Exceptional Children (ABK).

4. The assessment system includes: (a) the assessment used is an authentic assessment; (b) there are two report cards for Exceptional Children (ABK). 


\section{Bibliography}

Amstrong, T. (2009). Multiple Intelligences in the Classroom. USA: Julie Houzt.

Chatib, M. (2011). Gurunya Manusia: Menjadikan Semua Anak Istimewa dan Semua Anak Juara. Bandung: Kaifa Learning.

. (2013). Kelasnya Manusia: Memaksimalkan Fungsi Otak Belajar dengan Manajemen Display Kelas. Bandung: Kaifa Learning.

(2014). Sekolahnya Manusia: Sekolah Berbasis Multiple Intellegences di Indonesia. Bandung: Kaifa Learning.

DePorter, B. (2013). Quantum Learning Membiasakan Belajar Nyaman dan Menyenangkan. Bandung: Kaifa Learning.

. (2013). Quantum Teaching. Bandung: Kaifa Learning.

Dirman. (2014). Penilaian dan Evaluasi. Jakarta: Rineka Cipta.

Florian, L. (2010). Preparing teachers for inclusive education: using inclusive pedagogy to enhance teaching and learning for all. Cambridge Journal of Education Vol. 40, No.4, December 2010, 369-386.

Gangadevi. S. (2014). Multiple Intelligence Based Curriculum to Enchance Inclusive Education to Bring Out Human Potential. International Journal of Advanced Research (2014), Volume 2, Issue 8, 619-626.

John, H. (2010). Mengapa Siswa Gagal. Jakarta: Penerbit Erlangga.

Kristiani, D. (2016). Pengelolaan Pembelajaran IPA Kelas V di SD Negeri Gambirsari Surakarta. Surakarta: Sekolah Pascasarjana UMS.

Kurniasih, N. (2009). Manajemen Pendidikan di SMP Alam Ar Ridho Semarang Tahun 2009. Salatiga: Sekolah Tinggi Agama Islam Negeri Salatiga.

Loccaino, V. (2010). General Education Teachers Need to be Prepared to Co-Teach the Increasing Number of Children with Autism in Inclusive Setting. International Journal of Special Education, Vol 25 No 32010.

Mahmudah. (2016). Manajemen Pembelajaran Kelas Inklusi di SD Negeri 7 Sidokumpul. E-Journal-Unesa. Volume 01 Nomor 01 Tahun 2016, 0-216.

Mangunsong, F. (2009). Psikologi dan Pendidikan Anak Berkebutuhan Khusus Jilid Kesatu. Depok: Lembaga Pengembangan Sarana Pengukuran dan pendidikanPsikologi Kampus Baru UI.

Mangunsong, F. (2011). Psikologi dan Pendidikan Anak Berkebutuhan Khusus Jilid Kedua. Depok: Lembaga Pengembangan Sarana Pengukuran dan pendidikanPsikologi Kampus Baru UI. 
Nuridin, Jupriyanto, Elvrida Rosalia Indraswari

Masykuroh, A. (2015). Manajemen Pembelajaran Pendidikan Agama Islam untuk Anak Autis pada jenjang SD di Sekolah Luar Biasa-ABCD Tunas Pembangunan 2 Boyolali Tahun 2015. Surakarta: IAIN Surakarta.

Ormrod, J. (2009). Psikologi Pendidikan Membantu Siswa Tumbuh dan Berkembang. Jakarta: Penerbit Erlangga.

Peraturan Menteri Pendidikan Nasional RI Nomor 41 Tahun 2007.

Praptiningrum, N. (2009). Metode Multisensori untuk Mengembangkan Kemampuan Membaca Anak Disleksia di SD Inklusi. Jurnal Penelitian Ilmu Pendidikan, Volume 02, Nomor 2, September 2009.

Sanjaya, W. (2015). Perencanaan dan Desain Sistem Pembelajaran Edisi Pertama. Jakarta: Prenadamedia Group.

Sugiyono. (2015). Metode Penelitian Pendidikan Pendekatan Kuantitatif, Kualitatif, dan $R \& D$. Bandung: Alfabeta.

Supardi. (2016). Penilaian Autentik Pembelajaran Efektif, Kognitif, dan Psikomotor. Jakarta: Raja Grafindo Persada.

Syah, M. (2014). Psikologi Pendidikan Dengan Pendekatan Baru. Bandung: PT Remaja Rosdakarya.

Triani, W. (2013). Konsep Sekolah Inklusi yang Humanis. Yogjakarta: Familia Pustaka Keluarga.

Triwiyanto, T. (2015). Manajemen Kurikulum dan Pembelajaran. Jakarta: Bumi Aksara.

Wijayanto, D. (2012). Pengantar Manajemen. Jakarta: PT Gramedia Pustaka Utama.

Undang-undang Nomor 20 Tahun 2003 tentang Sistem Pendidikan Nasional 